\title{
FINNIC TETRAMETER IN J.R.R. TOLKIEN'S THE STORY OF KULLERVO IN COMPARISON TO W.F. KIRBY'S ENGLISH TRANSLATION OF THE KALEVALA
}

Keywords: trochaic tetrameter, Finnic metrics, Kalevala-metre, Kullervo, Tolkien

\begin{abstract}
The Finnish epic Kalevala is written in the so-called Finnic "Kalevala-metre", typical of Finnic oral poetry. Its main features are the use of trochaic tetrameter (octosyllabic lines), alliteration, assonance, sound parallelisms and the repetition of words. It is difficult to retain those features in translation but one of the early successful attempts was the first full English translation directly from Finnish by William Forsell Kirby (1907). Kirby's translation was a source of inspiration and the linguistic model for The Story of Kullervo, a tale written by John Ronald Reuel Tolkien (probably in 1912), based on one of the Kalevala's stories. Our aim is to compare those texts.
\end{abstract}

Ever since its publication in 1835 , the Finnish epic Kalevala has been a rich source of inspiration for readers in both Finland and abroad. Soon after, in 1855, the American poet, Henry Longfellow, composed an "Indian" epic poem The Song of Hiawatha, written in trochaic tetrameter, the same as in the Kalevala. At the same time, the

Longfellow had a copy of the Finnish original, but read the epic mainly in Anton Schiefner's German translation (Kalewala, das National-Epos der Finnen, 1852), and Matthias A. Castrén's Swedish translation (Kalevala, 1841); cf. e.g. Moyne (1963). The two translations adopted the Kalevala-metre with some success.

Later e.g. Tolkien will comment on Longfellow's epic: "not only the metre, but the idea of the poem, and much too of the matter and incident, was pirated for 'Hiawatha' - 'Hiawatha' is in fact the first literary offspring of the Kalevala, [...]. 'Hiawatha' is not a genuine storehouse 
Estonians set out to compose a similar epic modelled on the Kalevala: this Estonian national poem is the Kalevipoeg, published in instalments between 1857 and $1861{ }^{2}$ Inspired by the Finnish and Estonian epics, the Latvian poet Andrejs Pumpurs wrote Lä čplessis, the national epic of the Latvians, in $1888 .{ }^{3}$

Thus the Kalevala has had an important role in influencing world literature, and among its admirers we can find not only Finns (such as the writer Aleksis Kivi, the composer Jean Sibelius, or the painter Akseli Gallen-Kallela) and their Estonian and Latvian neighbours, but also many foreigners from further afield, for example J.R.R. Tolkien, who read the Kalevala in the 1907 English translation by W.F. Kirby in 1911, which inspired him to write The Story of Kullervo. Later, many characters and words in his Elfish language of Quenya were also based on the Kalevala and the Finnish language (cf. e.g. Battarbee 1993; Kahlas-Tarkka 2014).

\section{The Kalevala and its context}

The 1835 first edition of the Kalevala is a compilation of old Finnic folk songs, oral poetry and legends meticulously collected by Elias Lönnrot (1802-1884), a Finnish doctor and philologist. ${ }^{4}$ During his many trips to rural regions, ${ }^{5}$ he listened to peasant-singers (usually men), ${ }^{6}$ considered almost wizards or elders, who sang old songs from memory. Lönnrot's aim was to compose an epic comparable to Homer's Iliad and Odyssey or to the Icelandic Edda (Voigt 1990: 247-249). For this reason,

of Indian folklore, but a mild and gentle bowdlerizing of the Kalevala coloured with disconnected bits of Indian lore" (T117).

2 This compilation, begun by Friedrich Robert Faehlmann (1798-1850) and finally completed by his colleague Friedrich Reinhold Kreutzwald (1803-1882), was first published in pieces in a literary Estonian journal, with parallel translation in German, while its final version published as a book appeared in 1861 in German and in 1862 in Estonian.

The titles of the two epic poems are related: Fin. Kalevala is 'Kaleva place/land/district', while Est. Kalevipoeg means 'Kalev's son'. In Finnic folk tradition, Kale(h)v(a)/Kalevi was a supernatural giant or an extraordinary man. He appeared not only in Finnic legends, but also in Old Russian oral epic poems as Kolivan Kolivanovitch (Кольвван Кольванович). The name itself might come from a Scandinavian tribe Kylfings (or Kolbyags, Est. Kalevid, Old Russ. Колбяги); or from Lith. kalvis 'smith', but other hypotheses are possible too (cf. SSA I: 283-284; Laugaste 1990: 277). It should also be noted that one of the earliest names of Tallinn, the present-day capital of Estonia, was Kolyvan (Russ. Колььвань), which resembles the Genitive form of the name Kaleva. Needless to say, numerous hypotheses have been put forward about the origin of this name (see e.g. Setälä 1907: 255-262) and the debate continues.

3 In all three epics there are also some similar themes and symbols, although often in other forms and under other names. Moreover, Kalevipoeg and Läčplēsis are more sophisticated poetic works.

4 Lönnrot was far from the first to develop an interest in Finnish folk poetry. Several decades earlier, Henrik Gabriel Porthan, a professor at the Academy of Turku and the "father of Finnish history", wrote a seminal work De poësi Fennica (1766-1768), in which he emphasized the wealth of Finnish oral poetry and folk traditions.

5 In the east, north and south (not only across Finland, but even in Estonia), and particularly in the region of Karelia on the edge of the eastern border of Finland.

6 In Estonia, and in Ingria on the southeastern shore of the Gulf of Finland, such singers were mainly women (cf. Laugaste 1990: 279; Järvinen 2010: 81). 
he put together random oral folk tales to create a longer poem, sometimes meddling with and rewriting portions of the text. ${ }^{7}$ His first Kalevala immediately became a huge success in Finland, gaining the status of a cornerstone of Finnish national identity: Finns considered it part of their cultural heritage, stimulating the growth of their common consciousness as a nation, pride in their language ${ }^{8}$ and a thirst for independence and nationhood. ${ }^{9}$ This "Old Kalevala" of 1835 not only awakened admiration in Finland, but also abroad, and soon many translations began to circulate in Europe: first in 1840 in extracts in Estonian and in German; in 1841 in Swedish (a complete version); later in French in 1845 and in English in 1846.

However, the final version of the Kalevala (the "New Kalevala") did not come out until 1849 and its translations and retranslations started all over again. Today, the Kalevala has global renown and has been translated into many languages. ${ }^{10}$

\section{The first versions of the Kalevala in English}

Among the many translations and adaptations of the Kalevala in English, ${ }^{11}$ the first five versions are:

1. 1846 (London): this first English summary-translation was published in long extracts in prose by Charles Frederick Henningsen (1815-1877), a mercenary of Danish and Irish descent. In his account of Eastern Europe and Russian Empire, ${ }^{12}$ he gives a summary of the Kalevala and explains its specificity to English-speaking readers:

Like all Finnish poetry, both ancient and modern, its verse is alliterative instead of being in blank or rhymed; but from the nature of the language, this singular kind of versification is full of harmony; and, to judge from the facility with which it is improvised by the peasantry, must be of easy construction. (Henningsen 1846 II: 169-170)

7 Lönnrot retained approximately 95-97\% of the original texts (cf. e.g. Kaukonen 1979: 72).

8 W.R. Mead (1962) highlights the significant role of the Kalevala in the close connection of the folklore and language in the awakening of the national identity and socio-political endeavours of the Finns. Until then, Finnish had been considered a rather poor peasant patois with many dialects, far inferior to Swedish. Reading the Kalevala also contributed to the development of the standards of the common written language (cf. Punttila, Issakainen 2003).

$9 \quad$ Finland had never been independent, remaining under Swedish rule until 1809, when, after the war between Sweden and Russia, it became an autonomous part of the Russian Empire. The Finns finally proclaimed independence in 1917.

10 A list of the translations of the Kalevala is available on the website of the Kalevala Society (Kalevalaseura): https://kalevalaseura.fi/en/about-kalevala/translations-of-the-kalevala/ (April 2021).

11 See the complete list of the Kalevala's English-language translations: https://kalevalamaailmalla. kalevalaseura.fi/kalevala-englanniksi (April 2021).

12 Henningsen followed the French model of the Kalevala's account by Louis-Antoine Léouzon Le Duc, French journalist, writer, historian and diplomat, who published long extracts in prose of the Kalevala in his book about Finland: La Finlande, son histoire primitive, sa mythologie, sa poésie épique, avec la traduction complète de sa grande épopée, le Kalevala, son génie national et sa condition politique et sociale depuis la conquête russe (1845). 
And he gives a sample in English:

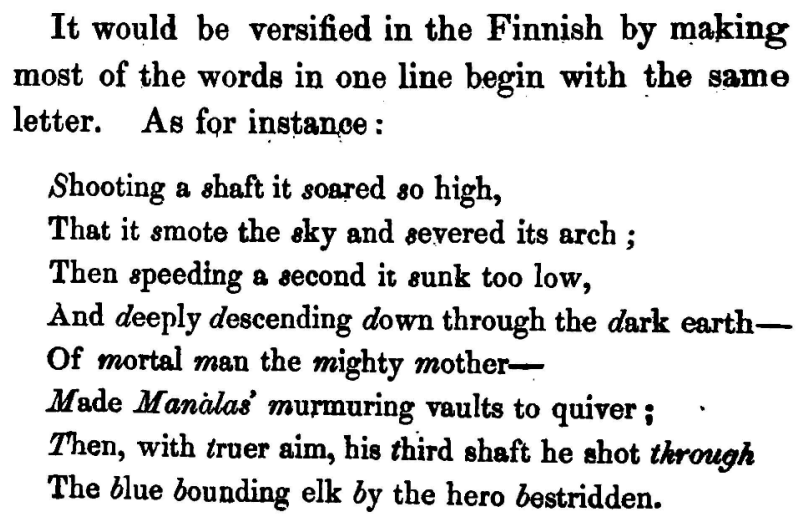

(Henningsen 1846 II: 170)

2. 1868 (New York): Selections from the Kalevala. Translated from a German version by John Addison Porter (1822-1866), an American professor of chemistry at Yale University. The book contains the 3 rd and 4 th runos (poems) and partially the 1 st and the 2nd, because Porter died before he finished his translation, so the publication came out thanks to his friend, Eugene Schuyler. The basis of his version was Anton Schiefner's German translation (1852), which was very popular at the time. In his work, Porter was supported also by a Finnish friend, the chemical engineer August Fredrik Soldan (cf. Forselles 2012). ${ }^{13}$

3. 1888 (New York): The Kalevala. The epic poem of Finland - the first complete English version, probably based mainly on the German translation. The translator was John Martin Crawford (1845-1916), an American doctor and professor of physiology at Pulte Medical College in Cincinnati. He was supported in his translation, among others, by the abovementioned Soldan, as well as by Thomas Conrad Porter, an American botanist who had also tried to translate the Kalevala a few years earlier and who provided him with his own translations. In addition, he reviewed and corrected Crawford's entire translation (Setälä 1910b: 31).

4. 1893 (London): Finnish legends for English children - a shorter adaptation of Crawford's English version by R. Eivind.

5. 1907 (London): Kalevala, the land of heroes by William Forsell Kirby (1844-1912), an English entomologist, who specialized in butterflies. According to Setälä (1910b: 32), Kirby became interested in the Kalevala thanks to his colleague, Edward Clodd, English anthropologist, who visited Finland himself. They decided to translate the epic together. Initially, Kirby used Schiefner's German translation,

13 Soldan was the director of the Mint of Finland. His daughter Venny married Juhani Aho (originally Johannes Brofeldt), a famous Finnish writer. 
but gradually learned Finnish enough to be able to compare the translation with the original. However, because of the publication of Crawford's translation, Clodd backed out of the joint venture, and Kirby had no choice but to go on with the work alone, although he had to interrupt it for a few years, until, at the instigation of some Finns, he completed his translation. In his work, he wanted to convey the same effect in the form as Longfellow did in his Hiawatha (Setälä 1910b: 32-33). It was the first English translation made directly from Finnish, with great respect for the archaic spirit of the poem and its form, making this translation a very faithful rendition (cf. Räihä 2012).

Tolkien read Kirby's version in 1911, while a student in Birmingham. Despite his fascination and admiration for the poem, he "thought Kirby's translation unsatisfactory" (Flieger 2015: xi), and it was a source of inspiration for his subsequent attempts to recreate one of the Kalevala's stories: The Story of Kullervo.

\section{The uniqueness of the form of the Kalevala}

The Kalevala is written in the so-called "Kalevala-metre" (in Finnish Kalevala(n)mitta, and in Estonian Kalevala-mõõt or regivärss or regilaul) ${ }^{14}$ or Finnic tetrameter. Some scholars have even termed it the "Kalevala language" (cf. e.g. Kuusi 1994).

This old Finnic poetic oral language has no rhymes or stanzas. Its most salient features are the use of trochaic tetrameter (an octosyllabic line with quadripartite trochaic rhythm), alliteration, assonance, sound parallelisms, and the repetition of words. ${ }^{15}$ Such prosodic and phonic features give the text a soft harmony and rhythmic melody. The Kalevala-metre was very popular in folk songs and orally transmitted poems, as well as in incantations and charms. The songs were usually sung or recited from memory by bards (Fin. runonlaulajat), often accompanied by the kantele, a wooden plucked instrument with five strings, and that is why the melody "covered a narrow range, usually consisting of only five notes” (Järvinen 2010: 76).

This metrical structure was typical of Finnic-speaking areas (Finland, Karelia, Savo, Ingria, Estonia), and was an indigenous feature of the old Finnic oral poetic tradition (Korhonen 1994). ${ }^{16}$ In western Finland, it started to vanish at the end of the 16th century under the influence of the Reformation and its rhymed and stanzaic poetics (Kallio 2016), which spread with the development of written Finnish, mainly in a Lutheran religious environment. There are relatively few written sources containing excerpts of Finnish oral poetry before this era, but the Kalevala-metre is still seen in Finnish manuscripts such as Piispa Henrikin surmavirsi ("The deathlay of Bishop Henry"), which is a 17th-century version of a tale that dates back to the Middle Ages.:

14 For other names, see e.g. Kallio, Frog, Sarv (2016-2017).

15 Among the most important studies on the Kalevala-metre and its rules and features, see e.g. Sadeniemi (1951), Kiparsky (1968), Schellbach-Kopra (1991), Kuusi (1994), Leino (1994).

16 However, it does not appear in traditional Saami (Lappish) poetry, even though the Saamis are linguistic cousins of the Finns. 
In the 19th century, this old oral singing culture was only alive in eastern Finnic areas: eastern Finland, Karelia and Ingria. Lönnrot collected old songs in those regions during his travels and formulated a plot for the epic on that basis. At the same time, he listened to the songs' melody and noted the manner in which they were sung. However, for the publication of the Kalevala, "Lönnrot made some changes to the language of the folk poems. First of all, he unified the metre, making it more regular and correct than in the original poems" (Järvinen 2010: 77).

With the Kalevala established as the Finnish epic, Lönnrot raised peasant singing to the level of lettres de noblesse and henceforth it was referred to as "Kalevalametre". Thanks to his efforts, Finnic tetrameter started to be more widely known and appreciated in literature, appearing later in the Estonian epic Kalevipoeg.

However, it is important to note that this peasant singing took slightly different forms in various Finnic regions:

Kalevala-meter is based on both the length and the stress of syllables. Typically, a long syllable carrying the main stress should be placed in a metrically strong poetic position, and a short syllable carrying the main stress in a weak poetic position. This rule is most strict towards the end of a verse. In Finnic languages, the main stress always falls on the first syllable of a word or a compound. Typically, one verse consists of eight to ten syllables that are organized in four poetic feet (or eight poetic positions). In practice, however, these rules manifest in different regional and local variations. Occasionally, a line may have anywhere from five to twelve syllables. (Kallio 2017: 334)

As to its origin, it "has been estimated to have developed about 1000-500 B.C. among proto-Finnic groups living near the Gulf of Finland” (Järvinen 2010: 76). As Frog (2019) states, its syllabic structure might be a Uralic legacy, but probably its actual shape is a result of the "creolization" of the Proto-Scandinavian alliterative tetrameter in Late Proto-Finnic, during more intensive contacts with Scandinavian languages, when some changes occurred in the culture of Finnic peoples: "the Finnic tetrameter would have emerged in a multilingual environment where people had native-like sensitivity to both Finnic and North Germanic poetics” (Frog 2019: 66).

\section{The metrical structure of the Kalevala}

The typical metrical structure of traditional Finnic oral poetry is an eight-syllable verse ${ }^{17}$ containing four pairs of stressed and unstressed syllables.

In Finnish, the primary stress falls on the first syllable, while the secondary stress is possible on the third syllable when a word has four syllables or more. ${ }^{18}$ Also, when a word is composed of two or more lexemes, each of them has the stress usually on the first syllable too.

Therefore, in the classical trochaic tetrameter with two-syllable words, the stress falls on the 1st, the $3 \mathrm{rd}$, the 5 th and the 7 th syllables, e.g.:

${ }_{17}$ A longer verse with nine or ten syllables is rare, but it does exist in the epic, e.g. Olipa nuori Joukahainen (F3: 21), Vaski- oli hattu hartioilla (F2: 117).

18 Sometimes, when the third syllable is short and the fourth is long, the secondary stress can fall on the fourth. 


\section{Tuli suuri tuulen puuska (F1: 127) $1234 / / 5678$}

With longer words too, the caesura most often falls after the second foot, so the most frequent verse consists of two quadrisyllabic hemistichs, e.g.:
aina $y k \sin$ ollessansa (F1: 119)
$1234 / / 5678$
asuinmaata arvaellen (F1: 182)
$1234 / / 5678$

However, this ideal, rhythmical structure is not always possible because of trisyllabic or longer odd words. Only the first foot of the verse is freer than the others and can contain even three or four syllables.

This "broken" tetrameter (Fin. murrelmasäe) often lacks a regular caesura and this modified prosodic line helps to avoid monotony:

$\begin{array}{ll}\text { Mieleni minun tekevi, (F1: 1) } & \mathbf{1 2 3 4 5 / / 6 7 8} \\ \text { aivoni ajattelevi (F1: 2) } & 123 / / 45678 \\ \text { vatsanvaivoissa kovissa (F1: 148) } & 12345 / / 678 \\ \text { Oi Ukko, ylijumala (F1: 169) } & \mathbf{1 2 3 / / 4 5 6 7 8}\end{array}$

Sometimes, to obtain an octosyllable in each line, it is necessary to apply an elision (or apocope), e.g. ain' on (F26:107) < aina on, mit' olet (F28: 90, 106) < mitä olet, löip' on (F49: 226) < löipä on, etc.

Moreover, in many places we can see the use of archaic intervocalic $h$, for example in kuolleheksi (F36: 89), which makes two syllables to read (while the word in the standard Finnish of today has one long vowel kuolleeksi). In other places, a diaeresis is marked with an apostrophe to read two short vowels instead of one long vowel, e.g. puhe'et (F1: 8) < puheet, etc.; or a diphthong: e.g. keihä'itä (F49: 314) < keihäitä.

Another main rule of the Kalevala says that the line never ends with a monosyllable. And the last syllable of the last word in the line should be short.

Here we will see how Kirby's English translation of the Kalevala managed to retain the same metrical structure, taking into consideration the fact that the trochaic metre is natural for Finnish because the stress falls on the first syllable, while the stress in English is variable but often on the last syllable, making iambic metre more natural. However, Longfellow managed to compose his Song of Hiawatha in trochaic tetrameter ${ }^{19}$ (cf. Moyne 1963), and Shakespeare employed it even earlier in works such as Midsummer Night's Dream or Macbeth.

Let us consider a few lines where the regular trochaic tetrameters intertwine with the irregular syllabic segments, a frequent occurrence in the Kalevala:

19 E.g. the beginning of chap. IV: Out of childhood into manhood:

Now had grown my Hiawatha, Skilled in all the craft of hunters, Learned in all the lore of old men, In all youthful sports and pastimes, In all manly arts and labors. (Longfellow 1898 IV: 1-6) 
Tuli suuri tuulen puuska, iästä vihainen ilma; meren kuohuille kohotti, lainehille laikahutti. Tuuli neittä tuuitteli, aalto impeä ajeli ympäri selän sinisen, lakkipäien lainehien: tuuli tuuli kohtuiseksi, meri paksuksi panevi. (F1: 127-136)
Then a storm arose in fury, From the East a mighty tempest, And the sea was wildly foaming, And the waves dashed ever higher. Thus the tempest rocked the virgin, And the billows drove the maiden, O'er the ocean's azure sur/face, On the crest of foaming billows, Till the wind that blew around her, And the sea woke life within her. (K)

The stressed vowels are in bold. In English, the stress depends on prosodic units, as well as on pragmatic emphasising, so this range is approximate. However, since the monosyllables are dominant in this passage, iambs generally intertwine with trochees in dissyllabic feet, interspersed with anapaests in trisyllabic ones.

\section{Alliteration and assonance}

Kalevala-metre is usually accompanied by the phenomena of imitative harmony such as alliteration (repeating the same consonants) and assonance (vowels) in sequences of words in verses. These features give Finnic verse its phonic fluidity and its preferred form is to even repeat the same consonant and the same vowel at the same time. This poetic device is difficult to convey in other languages (however, simple alliteration is well known in old Germanic poems, something which is seen particularly clearly in Icelandic texts).

The resemblances at the end of the verses provide a substitute for rhymes. Such an accumulation of similar sounds produces a phonic synergy effect and triggers more aesthetic force in the ears of its listeners. ${ }^{20}$

In the excerpts below, we can see alliteration and assonance, with the domination of one or two vowels in each verse:

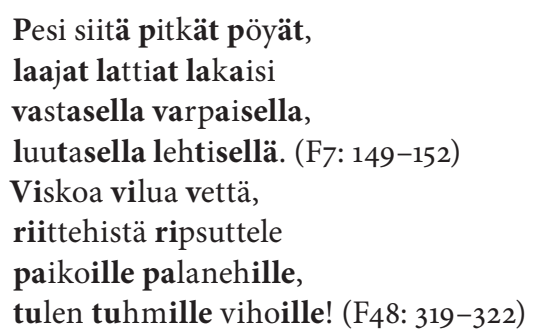

After this she washed the tables, swept the wide-extended flooring, With the broom of twigs all leafless, Then with broom of leafy branches. (K) Sprinkle me with freezing water, Sprinkle me with icy water, On the places scorched so badly, And the burns the fire has caused me. (K)

In his English translation, Kirby is unable to retain such repetitions of sounds, but tries to repeat words or their stems.

${ }^{20}$ It should also be remembered that in Finnic languages (except Estonian and Livonian), there is a phenomenon called "vowel harmony", which matches the type of the vowels of the root and endings. In Finnish: on the one hand: $a, o, u$; on the other hand: $\ddot{a}, \ddot{o}, y$ [y], while the vowels $e$ and $i$ are neutral. 


\section{Parallelisms of line endings and word repetition}

Sound parallelisms in the Kalevala are both abundant and complex, serving to repeat a thought with a fairly coherent phonic ornament: they not only contain alliterations and assonances at the same time, but also similar words are accumulated in a single verse. Moreover, the neighbouring verses resemble each other in the choice of analogous words, which look like final and internal rhymes. Some verses seem to be holorhymes, e.g.:

\author{
Enkä lähe Inkerelle, \\ penkerelle, pänkerelle; \\ siell' on nälkä, kaiken nälkä: \\ puun nälkä, pärehen nälkä, \\ ve'en nälkä, vehnän nälkä, \\ rukihisen leivän nälkä. (F11: 55-60) \\ Pohetahan, potketahan, \\ ve'etähän, vennätähän. \\ Saa'ahan kaloja kyllin: \\ ihveniä, ahvenia, \\ tuimenia, taimenia, \\ lahnoja, lohikaloja, \\ kaikkia ve'en kaloja: (F48: 97-101)
}

\author{
Nor to Ingerland I'll travel, \\ Nor its slopes and shores will visit. \\ There is hunger, nought but hunger \\ Want of trees, and want of timber, \\ Want of water, want of wheatfields, \\ There is even want of ryebread. (K) \\ Thus they cast the net and pushed it, \\ And they drew the net and dragged it, \\ Captured fishes in abundance, \\ And they captured perch in plenty, \\ Salmon-trout in great abundance, \\ Bream and salmon too they captured, \\ All the fishes of the water, $(\mathrm{K})$
}

These examples particularly impressed Tolkien, who noted two verses of these above-mentioned passages in his essays "On The Kalevala or Land of Heroes" and "The Kalevala", where he wrote:

[...] in the poetry meaningless syllables and even meaningless words that merely sound jolly are freely inserted. [...] I don't mean to say that this sort of thing is done often enough to reduce the songs to nonsense rhymes with flickers of sense; but the mere fact that such things are possible at all even if it may be for special effect or emphasis is sufficiently astonishing. (T116, cf. also T77)

The Kalevala's English translation by Kirby renders this parallelism only partially, and in some places, there are no repetitions at all.

The paper will now turn to a juxtaposition of Kirby's English form of the Finnic verse with Tolkien's in his attempt to rewrite one of the Kalevala's stories.

\section{The Story of Kullervo by Tolkien}

\section{Tolkien's reading of the Kalevala}

Tolkien read the Kalevala in Kirby's translation in the first half of 1911 (when still a student at King Edward's School in Birmingham), which inspired him deeply, and "he determined to find an edition in the original Finnish as soon as possible" (Carpenter 2002: 74). He was so enthusiastic that when he went to Oxford that year, he borrowed C.N.E. Eliot's Finnish Grammar "in an attempt to teach himself 
enough Finnish to read the original. He was largely unsuccessful, and ruefully confessed he had been 'repulsed with heavy losses'” (Flieger 2015: xii). However, the Kalevala stayed with him: "Tolkien was fond of Finnish, modelled aspects of Quenya on it, and furthermore admired the Kalevala as a product of exactly the kind of literary rescue-project which he would have liked to see in England" (Shippey 2001: 244).

He decided to retell the story of Kullervo, one of the main figures of the Kalevala, but this early work remained unfinished, and exists as rough draft in a single manuscript (MS Tolkien B 64/6) in the Bodleian Library. It was probably written during the years 1912-1914, and "almost certainly" before his war service intervened (he was sent to France in 1916) (Flieger 2015: xii). In addition to the story of Kullervo, Tolkien also wrote a draft of two essays "On The Kalevala or Land of Heroes" and "The Kalevala" for his college talk.

The story is similar to the thread of Kullervo in the Kalevala, but Tolkien changed almost all of the names and surnames, except Kullervo, also referred to as Sākehonto, Sāki, Sāri, or Honto. ${ }^{21}$

\section{The figure of Kullervo in the Kalevala and Tolkien's story}

Kullervo is the most tragic figure of the Kalevala and his story amounts to something of an independent plot in the epic. Lönnrot constructed this tale "from several independent epic folk songs" (Järvinen 2010: 37), but there is a hypothesis that it is borrowed from the story of Amleth, a Scandinavian legend which also inspired Shakespeare to create the character of Hamlet (Setälä 1903, 1907, 1910a). It is also similar to the Greek myth of Orestes (Jankó Szép 2014: 62).

The story of Kullervo in the Kalevala covers six poems (runos): 31-36, in total 2196 lines (according to Järvinen 2010: 37).

Born a strong boy with magical powers, he is the son of Kalervo, who is killed by his brother Untamo. The child is kidnapped and raised by Untamo as a servant. However, Untamo hates him and tries to kill him in three ways (by drowning, burning, and hanging). Finally, Untamo gives him many tasks to do, but Kullervo fails all of them, and Untamo decides to sell him to the smith Ilmarinen, whose treacherous and spiteful wife gives the boy bread with a stone inside, on which Kullervo breaks his knife. In revenge, Kullervo summons up bears and wolves to kill her. Then he runs away, laments his fate and decides to kill Untamo, but in the woods he meets the Lady of the Forest who helps him to find his family. In the house, he finds his mother and his father (which is an illogical fact, because his father has already been murdered by Untamo), as well as his brother and one sister. His mother tells him that his other sister was lost while gathering berries. During his stay at home, he undertakes many tasks but fails again. Finally, his father sends him to pay the landdues, and on the way back Kullervo meets a few girls who he tries to seduce, but in

21 Later, Tolkien created a similar fictional character in his legendarium: Túrin Turambar (Helms 1981: 6-8 and passim). 
vain. However, with the last of the girls he succeeds. Afterwards, they tell each other who they are, and it turns out that she is his lost sister. The distraught girl throws herself into a waterfall, and Kullervo hurries home, where he reveals the terrible truth to his mother. He wants to kill himself, but his mother tries to dissuade him from suicide. He sticks to his decision but determines that first he should take revenge on Untamo, so he leaves home. He destroys and burns the homestead and kills all the people on Untamo's land, including Untamo himself. At the same time, his family dies too (for unknown reasons), and he returns to an empty house, where only his dog is still alive. He goes to the forest and when he arrives at the place where he met his sister, feeling strong remorse, he falls on his sword.

In Tolkien's story, Kullervo is born with his twin sister, who is called Wanōna or Oanōra (in the Kalevala she is his elder, nameless sister). Both children meet Kalervo's dog Musti/Mauri who has magical powers, a fact which later helps Kullervo when Untamo tries to kill him three times. Later, during his stay at the smith Āsemo's house, Kullervo is not alone, but has his dog with him. Some other events are rearranged:

1. when dying, the smith's wife curses Kullervo;

2. on his way to his parents' house, Kullervo meets his lost sister in the woods;

3. they spend a few days together in the woods;

4. after the death of his sister, Kullervo does not reach his family's house, but goes directly to Untamo's land;

5. Kullervo kills everyone and destroys everything (with the help of bears and wolves) except Untamo's house, where he spends one night;

6. the dog is killed by bears and wolves;

7. Kullervo's mother's ghost appears to him and tells him his own brother and sister are among those he murdered on Untamo's land;

8. Kullervo sets fire to the house;

9. Kullervo's farewell to his brother is at the beginning, and not at the end of the story.

Finally, there are changes to some names, e.g. the smith's name is Āsemo (not Ilmarinen); Untamo is also called Ulto; the knife broken on the stone in the bread is called Sikki.

\section{Parallel verses in Kirby's translation and Tolkien's story}

Tolkien's tale is a shorter adaptation of the Kalevala's story of Kullervo. The major part of the text is written in prose, blended with twenty "chunks of poetry", ${ }^{22}$ which vary in length: $20,14,3 \times 2,3,21,12,95,7,27,7,9,4,19,32,4,10,5,15$; a total of 310 lines, yet due to space constraints we will only focus on some of these here. In comparison to Kirby's translation of the Kalevala, we have found numerous similarities: the bolded words are identical, while the underlined words are synonymic:

22 The term used by Tolkien in his letters (see Flieger 2015: xii, 55, 139). 
In this scene, Kullervo makes a clearing in a near thicket, singing:

Let no sapling sprout here ever

Nor the blades of grass stand greening

While the mighty earth endureth

Or the golden moon is shining

And its rays come filtering dimly

Through the boughs of Saki's forest.

Now the seed to earth hath fallen

And the young corn shooteth upward

And its tender leaf unfoldeth

Till the stalks do form upon it.

May it never come to earing

Nor its yellow head droop ripely

In this clearing in the forest

In the woods of Sākehonto. (T14)

Kullervo's bitter farewell to his brother:

Not for thee shall I go weeping

If I hear that thou hast perished:

I will make me such a brother - (T18)
Let no sapling here be growing,

Let no blade of grass be standing,

Never while the earth endureth,

Or the golden moon is shining,

Here in Kalervo's son's forest,

Here upon the good man's clearing.

If the seed on earth has fallen,

And the young corn should shoot upward,

If the sprout should be developed,

And the stalk should form upon it,

May it never come to earing,

Or the stalk-end be developed.

$\left(\mathrm{K}_{31}: 283-294\right)^{23}$

Nor for you shall I be weeping,

If I hear that you have perished.

I will make me such a brother,

$\left(\mathrm{K}_{3} 6: \text { 95-97 }\right)^{24}$

The lament of Kullervo's mother:

[...]

Scarce thou knowest a mother's feelings

Or a mother's heart it seemeth [...]

I shall weep for thy destruction

[...] [different text]

Till they melt [the] snows around me

And the ground is bared and thawing

And the earth again grows verdant

And my tears run through the

greenness.

O my fair one $\mathrm{O}$ my nursling

Not thou knowest a mother's feelings,

Nor a mother's heart esteemest.

I shall weep for thy destruction,

[...] [different text]

Weep until the snows are slippery,

Till the ground is bare and slippery,

Lands unfrozen teem with verdure,

And my tears flow through the greenness.

$\left(\mathrm{K}_{3} 6: 135-148\right)^{25}$

Kullervoinen Kullervoinen

Sārihonto son of Kampa. (T19)

${ }^{23}$ In the original: Elköhön vesa venykö, / elköhön koretko korsi / sinä ilmoisna ikänä, / kuuna kullan valkeana / kaskessa Kalervon poian, / otoksessa oivan miehen! / Ottaisiko maa orahan, / nousisiko nuori laiho, / sekä korsi korteuisi, / jotta varsi varteuisi, / elköhön tereä tehkö, / varsi päätä valmistako!

24 In the original: Enkä itke mie sinua, / kuulisinko kuolleheksi. / Saan minä mokoman veljen.

25 In the original: Et älyä äitin mieltä, / arvoa emon syäntä. / Itkenpä minä sinua, / kun sun kuulen kuolleheksi, / väestä vähenneheksi, / sortuneheksi su'usta: / itken tulville tupamme, / siltalauat lainehille, / kujat kaikki kuurullani, / läävät länkämöisilläni; / lumet itken iljeniksi, / iljenet suliksi maiksi, / sulat maat vihottaviksi, / vihottavat viereviksi. 
The smith's wife starts to say prayers and charms for the protection of her cattle, when Kullervo goes to the fields as a herdsman:

Let him herd among the bushes And the milch kine in the meadow: These with wide horns to the aspens These with curved horns to the birches That they thus may fatten on them And their flesh be sweet and goodly. Out upon the open meadows Out among the forest borders Wandering in the birchen woodland And the lofty growing aspens. Lowing now in silver copses Roaming in the golden firwoods.

(T21-22)
Send the cows among the bushes, And the milkers in the meadow, Those with wide horns to the aspens, Those with curved horns to the birches, That they thus may fatten on them, And may load themselves with tallow, There upon the open meadows, And among the wide-spread borders, From the lofty birchen forest, And the lower growing aspens, From among the golden fir-woods, From among the silver woodlands.

$\left(\mathrm{K}_{32}: 37-48\right)^{26}$

And she continues to sing something akin to a prayer to a god (Jumala in the Kalevala, and Ilu in Tolkien's story) for protecting the cattle and getting them safe home. This long song spans $95 \operatorname{lines}^{27}$ (T22-25) and corresponds approximately to those between 49 and 303 in the runo 32 of the Kalevala.

Then come seven lines with charms to tree deities for getting cattle home:

Then Palikki's little damsel

And Telenda her companion

Take a whip of birch to scourge them

And of juniper to drive them

From the hold of Samyan's cattle

And the gloomy slopes of alder

In the milktide of the evening. (T26)
Pihlajatar, little damsel,

Katajatar, fairest maiden,

Quickly cut a branch of birch-tree,

Take a rod from out the bushes, [...]

And of juniper to scourge them, [...]

Drive the herd towards the household,

At the time for bathroom-heating;

Homeward drive the household cattle,

$\left(\mathrm{K}_{32}: 303-313\right)^{28}$

Afterward, she says a charm for the protection of her cattle from bears: 27 lines (T26) which correspond to the lines 315-486 in the same runo 32. Then follows a charm against wolves: seven lines (T27), which contain the sense of the lines 494-542 in the same runo.

26 In the original: Lasken lehmäni leholle, / maion antajat aholle, / hatasarvet haavikolle, / kourusarvet koivikolle; / työnnän kuuta ottamahan, / talia tavottamahan / ahomailta auke'ilta, / leve'iltä lehtomailta, / korke'ilta koivikoilta, / mataloilta haavikoilta, / kultaisilta kuusikoilta, / hope'isilta saloilta.

27 Therefore, we cannot quote it here, because of its length.

28 Pihlajatar, piika pieni, / Katajatar, kaunis neiti, / leikkoa lehosta koivu, / ota vitsa viiakosta, / [...] katajainen karjanruoska / [...] Aja karja kartanolle, / saunan lämmitä-panolle, / kotihin kotoinen karja. Here, in Kirby's translation, next to Pihlajatar 'Rowan-lady', we have the name Katajatar 'Juniper-lady' (Fin. kataja 'juniper' + fem. suff. -tar), as well as the noun juniper. In Tolkien's text, the names are different: Palikki, Telenda, Samyan. 
The next "chunk of poetry" is Kullervo's lament to his knife, broken by the stone in the bread. This kind of a "song to the knife" has nine lines (T29), and does not exist in the Kalevala, but verses 91-98 in the runo 33 contain a similar lament, although in different form, so it will not be quoted here.

Later we have four verses, where the smith's wife asks her mother-in-law to milk the cows:

Mother 'tis the kine need milking.

Do thou go and tend the cattle

For meseems I cannot finish

Kneading dough as I would have it.

( $\left.\mathrm{T}_{3} \mathrm{O}\right)$
Mother, go and milk the cattle,

Do thou go to tend the cattle,

For I think I cannot finish

Kneading dough as I would have it.

$\left(\mathrm{K}_{33}: 187-190\right)^{29}$

In the next 19 verses (T31-32), the smith's wife, having been torn to pieces by bears and wolves, curses Kullervo while dying. Yet such a curse does not exist in the Kalevala, where this woman only asks the god Ukko to kill Kullervo with an arrow.

In the next 32 verses, Kullervo explains his fate:

Wherefore have I been created?

Who has made me and has doomed me

Thus 'neath sun and moon to wander

'Neath the open sky forever?

Others to their homes may journey

That stand twinkling in the even

But my home is in the forest.

In the wind halls must I slumber

And in bitter rain must bathe me

And my hearth is midst the heather

In the wide halls of the wind blast

In the rain and in the weather.

Never Jumala most holy

In these ages of the ages

Form a child thus crooked fated

With a friendless doom forever

To go fatherless 'neath heaven

And uncared by any mother

As thou, Jumala, hast made me

Like a wailing wandering seagull,

Like a seamew in the weather

Haunting misty rocks and shoreland

While the sun shines on the swallow

And the sparrow has its brightness

And the birds of air are joyous

But that is never never happy.

I Sāri am not happy.
Wherefore have I been created,

Who has made me, and has doomed me,

Thus 'neath moon and sun to wander

'Neath the open sky for ever?

Others to their homes may journey,

And may travel to their dwellings,

But my home is in the forest,

And upon the heath my homestead.

In the wind I find my fire-place,

In the rain I find my bathroom.

Never, Jumala most gracious,

Never in the course of ages,

Form a child thus mis-created,

Doomed to be for ever friendless,

Fatherless beneath the heavens,

From the first without a mother,

As thou, Jumala, hast made me,

And hast formed me to be wretched,

Formed me like a wandering seagull,

Like a seagull on the lake-cliffs.

Shines the sun upon the swallow,

Brightly shines upon the sparrow,

In the air the birds are joyous,

I myself am never happy,

On my life the sun shines never,

29 In the original: Käypä, muori, lypsämähän, / raavahat rakentamahan! / Enpä itse ennättäisi / taikinan alustehelta. 
O Ilu, life is joyless.

\{I was small and lost my mother father I was young (weak) and lost my mother. All my mighty race has perished All my mighty race $\left(\mathrm{T}_{33}-34\right)$
And my life is always joyless. [... $]^{30}$

I was small, and lost my father, I was weak, and lost my mother, Dead is father, dead is mother, All my mighty race has perished,

$\left(\mathrm{K}_{34:} 45-80\right)^{31}$

These lines remain unfinished and seem only to be a draft of Tolkien's, as indicated by the strikethrough of a word and parentheses.

The next "chunk" has four lines, in which the girl asks Kullervo about his family:

Tell me now of all thy kinfolk

Of the brave race that thou springst from:-

Yea, a mighty race it seems me

Thine is, and a mighty father. $\left(\mathrm{T}_{37}\right)$
Tell me now of your relations,

What the brave race that you spring

\section{from,}

From a mighty race it seems me,

Offspring of a mighty father.

Kullervo answers in the following manner:

Nay my race is not a great one

Not a great one nor a small one:

I am just of middle station;

Kalervo's unhappy offspring

Uncouth boy and ever foolish

Worthless child and good for nothing.

Nay but tell me of thy people

Of the brave race whence thou comest.

Maybe a mighty race has born thee

Fairest child of mighty father. (T37)

And the girl replies:

Nay my race is not a great one

Not a great one nor a small one

I am just of middle station

Wandering maiden ever foolish

Worthless child and good for nothing.

$(\mathrm{T} 37-38)$

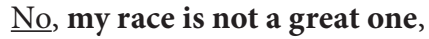

Not a great one, not a small one,

I am just of middle station,

Kalervo's unhappy offspring,

Stupid boy, and very foolish,

Worthless child, and good for nothing.

Tell me now about your people,

And the brave race that you spring from, Perhaps from mighty race descended,

Offspring of a mighty father.

$\left(\mathrm{K}_{35}: 199-208\right)^{33}$ $\underline{\text { No, }}$ my race is not a great one,

Not a great one, not a small one,

I am just of middle station,

Kalervo's unhappy daughter, Stupid girl, and very foolish,

Worthless child, and good for nothing.

$\left(\mathrm{K}_{35}: 211-216\right)^{34}$

${ }^{30}$ This is verse 70 , and the next $71-76$ had to be omitted, as there was no equivalent in Tolkien's text.

31 In the original: Piennä jäin minä isosta, / matalana maammostani. / Iso kuoli, äiti kuoli, / kuoli mun sukuni suuri.

32 In the original: Mist' olet sinä sukuisin, / kusta, rohkea, rotuisin? / Lienet suurtaki sukua, / isoa isän aloa.

33 In the original: En ole sukua suurta, / enkä suurta enkä pientä, / olen kerran keskimäistä: / Kalervon katala poika, / tuhma poika tuiretuinen, lapsi kehjo keiretyinen.

34 In the original: En ole sukua suurta, / enkä suurta enkä pientä, / olen kerran keskimäistä: / Kalervon katala tyttö, / tyhjä tyttö tuiretuinen, / lapsi kehjo keiretyinen. 
And the girl continues to tell him the truth about herself:

\author{
To the wood I went for berries \\ And forsook my tender mother. \\ Over plains and heath to mountains \\ Wandered two days and a third one \\ Till the pathway home I found not. \\ For the paths led ever deeper \\ Deeper deeper into darkness \\ Deeper deeper into sorrow \\ Into woe and into horror. \\ $\mathrm{O}$ thou sunlight $\mathrm{O}$ thou moonbeam \\ O thou dear unfettered breezes \\ Never never will I see thee \\ Never feel thee on my forehead. \\ For I go in dark and terror \\ Down to Tuoni to the River. ( $\left.\mathrm{T}_{3} 8\right)$
}

Living with my tender mother, To the wood I went for berries, 'Neath the mountain sought for raspberries. On the plains I gathered strawberries, Underneath the mountain, raspberries, Plucked by day, at night I rested, Plucked for one day and a second, And upon the third day likewise, But the pathway home I found not, In the woods the pathways led me, And the footpath to the forest. $\left(\mathrm{K}_{35}: 218-228\right)^{35}$

The above "chunk of poetry" is the last in Tolkien's story and its end has no corresponding text in the Kalevala, where the girl does not address her words directly to Kullervo. It should be noted that Tolkien made numerous repetitions here: deeper (5×), never ( $3 \times)$, O thou ( $2 \times)$, more than elsewhere in his Story of Kullervo.

From the abovementioned passages written in verse, a few observations can be made:

1. In the majority of the text, Tolkien only reshuffled Kirby's translation; moreover, many passages are identical.

2. In both texts, there are old forms or archaic words from the Middle English, e.g. verbs with endings $-s t$ and -th, e.g. endureth $\left(\mathrm{T}_{14}=\mathrm{K}_{31}\right.$ : 285$)$ or thou knowest $\left(\mathrm{T}_{19}=\mathrm{K}_{36}\right.$ : 138), or contraction 'tis ( $<$ it is). However, in Tolkien's text they are more frequent, e.g. the verbal form meseems ( $\mathrm{T}_{3} \mathrm{O}$ ), the possessive adjective thy or pronoun thine or the personal pronouns thou/thee appear more often, e.g. thou hast $(\mathrm{T} 18)=$ you have $\left(\mathrm{K}_{3} 6: 96\right)$.

3. Tolkien often uses more obsolete and dated synonyms, e.g. herd $\left(\mathrm{T}_{21}\right)=$ cows $\left(\mathrm{K}_{32}: 37\right)$, kine $\left(\mathrm{T}_{30}\right)=$ cattle $\left(\mathrm{K}_{32}: 37\right)$, milch kine $\left(\mathrm{T}_{21}\right)=$ milkers $\left(\mathrm{K}_{32}: 38\right)$, etc.

4. Alliterations and assonances are practically absent in both texts, but repetitions of words appear more often in Kirby's translation (almost in all the passages in some ways, cf. e.g. K35: 220-224 or K31: 283-288), while in Tolkien's text, they are rarer (the most striking examples are only in $\mathrm{T}_{19}$ and $\mathrm{T}_{3} 8$ ).

In conclusion, Tolkien's language is often more archaic and old-fashioned than Kirby's, but poorer in parallelisms.

35 In the original: emon ehtoisen eloilla / läksin marjahan metsälle, / alle vaaran vaapukkahan. / Poimin maalta mansikoita, / alta vaaran vaapukoita; / poimin päivän, yön lepäsin. / Poimin päivän, poimin toisen; / päivälläpä kolmannella / en tiennyt kotihin tietä: / tiehyt metsähän veteli, ura saatteli salolle. 


\section{The Kalevala-metre in The Story of Kullervo by Tolkien}

These "chunks of poetry" - as Verlyn Flieger reminds us in her notes and commentaries to this Tolkien's tale - are

[...] in the so-called "Kalevala metre", that Tolkien would have known from the Kirby translation in which he first read Kalevala. This is a rendering into English of the Finnish four-beat eight-syllable line, and is most familiar to English-speakers as the metre of Longfellow's Hiawatha. It is less monotonous in Finnish. (Flieger 2015: 55)

The trochaic rhythm in octosyllabic verses can generally be retained in both English texts thanks to monosyllabic and disyllabic words, e.g.

Nay my race is not a great one $\left(\mathrm{T}_{37}\right)$

12345678

Fairest child of mighty father ( $\left.\mathrm{T}_{37}\right)$

12345678
No, my race is not a great one $\left(\mathrm{K}_{35}: 211\right)$

12345678

Offspring of a mighty father ( $\left.\mathrm{K}_{35}: 208\right)$

12345678

However, monosyllables also appear at the end of the lines, which is not according to the rules of the Kalevala. Furthermore, the trochaic tetrameter is disturbed in many lines because of trisyllabic words and different stress, and it lacks a regular caesura, e.g.

To go fatherless 'neath heaven ( $\left.\mathrm{T}_{33}\right)$

$12 / 345 / / 6 / 78$
Fatherless beneath the heavens ( $\mathrm{K}_{34: 75)}$

$123 / 45 / / 6 / 78$

The lion's share of Tolkien's lines are octosyllabic, however, as we know, this early work of a twenty-year-old student remained unfinished and, in some points, it seems only to be a draft, so we can find verses with irregular number of syllables:

1. Nine (?) syllables:

Though mine ages have seen few summers ( $\left.\mathrm{T}_{13}\right)$

Scarce thou knowest a mother's feelings (T19)

Making flowers upon the hummocks ( T23 $)$

With the melody of the mead-horn ( $\left.\mathrm{T}_{23}\right)$

My Honeypaw that rules the forest ( $\left.\mathrm{T}_{2} 6\right)$

All this prayer and all this chanting ( $\mathrm{T}_{27}$ )

And from the Ocean bath to Westward ( $\mathrm{T}_{32}$ )

But that is never never happy ( $\left.\mathrm{T}_{34}\right)$

Maybe a mighty race has born thee ( $\left.\mathrm{T}_{37}\right)$

2. Seven (?) syllables:

That thou mayst not hear cowbells (T26)

Thy fate and end of terror ( $\left.\mathrm{T}_{32}\right)$

I Sāri am not happy (T34)

O Ilu, life is joyless ( $\left.\mathrm{T}_{34}\right)$ 
In other lines, there are opportunities to retain the same structure thanks to:

1. Different pronunciation

I shall weep for this our parting (T19) - if our pronounced as /a:(I)/, not /'aro(I)/

Wandering in the birchen woodland (T22) - if wandering pronounced as /'wond.ın/, not /'wonda.ın/; the same case in the verse Like a wailing wandering seagull ( $\left.\mathrm{T}_{33}\right)$ and in Wandering maiden ever foolish ( $\left.\mathrm{T}_{3} 8\right)$

Men shall hither come from Loke (T32) - if Loke pronounced /loke/loki/, not/lavk/

And shall hither come from Same ( $\left.\mathrm{T}_{32}\right)$ - if Same pronounced /same/sami/, not $/ \operatorname{serm}{ }^{36}$

2. Apheresis 'neath $<$ beneath

Thus 'neath sun and moon to wander $\left(\mathrm{T}_{33}\right)$ - cf. Thus'neath moon and sun to wander

(K34: 47)

'Neath the open sky forever? ( $\left.\mathrm{T}_{33}\right)$ - cf. 'Neath the open sky for ever? (K34:48)

To go fatherless 'neath heaven ( $\left.\mathrm{T}_{33}\right)$ - cf. Fatherless beneath the heavens ( $\left.\mathrm{K}_{34}: 59\right)$

3. Syncope o'er $<$ over

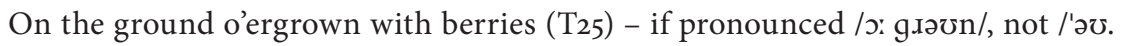
əg.əəชn/

4. Archaic contraction 'tis ( $<$ it is) in both texts

In the house 'tis glad and pleasant ( $\left.\mathrm{T}_{25}\right)$

On the waste 'tis ill to wander (T25)

And against a stone 'tis broken (

Mother 'tis the kine need milking ( $\left.\mathrm{T}_{3} \mathrm{O}\right)$

\section{Conclusions}

This paper has only considered the structure of "chunks of poetry" in Tolkien's The Story of Kullervo to see if it is the same Finnic tetrameter as in the Finnish original of the Kalevala and/or in Kirby's translation that inspired Tolkien. It has also sought to identify features closely related to Kalevala-metre, i.e. alliteration and assonance, as well as parallelisms and the repetitions of words.

The octosyllable of the Finnic metrical structure is retained wherever possible, but English accentuation is different, and the length of words does not always allow the division into two quadrisyllables and prosodic correspondences to be maintained when the main goal is to keep the sense (textual equivalence) of the original.

${ }^{36}$ However, we could compare this name Same with a similar noun in the verse But that when at Kame at milk tide (T24), where, despite the similar form, the name Kame should be read as one single syllable [keIm]. Nevertheless, in another line, a similar word has to be read as disyllabic: And shall fare to us from Kēme /keme/ (T32). 
Alliteration and assonance are almost absent in both Kirby's translation and Tolkien's story. Consequently, and also inevitably, the phonic and prosodic eurythmy is broken.

Like in the Finnish original, the selection of vocabulary is rather old-fashioned in both English texts, generally dating back to Middle-English, but Tolkien's language selection has slightly more old words and archaic forms.

The shape of the Finnish epic has its inherent characteristics which make up its exceptional metrical specificity, so discrepancies are inevitable between the form of the original text and its two English versions. Ultimately, the two English texts are very similar to each other in their differences to the Finnish original as Tolkien's text of one of the stories of Kalevala is merely a slightly rearranged version of Kirby's translation.

\section{Sources of examples}

F = Lönnrot E. 1995 (1835/1849). Kalevala. Helsinki: SKS.

$\mathrm{K}=$ [Lönnrot E.]. 1907. Kalevala: the land of heroes. [translated from the original Finnish by W.F. Kirby; 2 vols]. London: J.M. Dent \& Sons Ltd.

$\mathrm{T}=$ Tolkien J.R.R. 2015. The story of Kullervo. London: HarperCollins.

\section{References}

Battarbee K.J. (ed.). 1993. Scholarship \& fantasy: Proceedings of the Tolkien phenomenon, May 1992, Turku, Finland. Turku: University of Turku.

Carpenter H. 2002. J.R.R. Tolkien: A biography. London: HarperCollins.

Flieger V. 2015. Introduction. Notes and commentary. Tolkien, Kalevala, and 'The story of Kullervo'. - Tolkien J.R.R. The story of Kullervo. London: HarperCollins: vii-xxiii, $49-62,133-163$.

Forselles C. af. 2012. Englanninkieliset käännökset. Kalevalan muuttuvat ylikansalliset tehtävät. - Aarnipuu P. (ed.). Kalevala maailmalla: kansalliseepoksen kääntämisen kulttuurihistoriaa. Helsinki: SKS: 111-126.

Frog. 2019. The Finnic tetrameter - a creolization of poetic form? - Studia Metrica et Poetica 6.1: 20-78.

Helms R. 1981. Tolkien and the Silmarils. Boston: Houghton Mifflin.

Henningsen F.C. 1846. Eastern Europe and the Emperor Nicholas. [vol. 2]. London: T.C. Newby. Jankó Szép Y. 2014. Shakespeare ghosting in the Finnish Hamlet's tragedy. - Symbolon 15.27: 61-67.

Järvinen I.-R. 2010. Kalevala guide. Helsinki: SKS.

Kahlas-Tarkka L. 2014. Finnish: The land and language of heroes. - Lee S.D. (ed.). A companion to J.R.R. Tolkien. New York: Wiley \& Sons: 259-271.

Kallio K. 2016. Changes in the poetics of song during the Finnish Reformation. - Lehtonen T.M.S., Kaljundi L. (eds.). Re-forming texts, music, and church art in the Early Modern North. Amsterdam: Amsterdam University Press: 125-155.

Kallio K. 2017. Parallelism and musical structures in Ingrian and Karelian oral poetry. - Oral Tradition 31.2: 331-354. 
Kallio K., Frog, Sarv M. 2016-2017. What to call the poetic form - Kalevala-meter or Kalevalaic verse, regivärss, runosong, the Finnic tetrameter, Finnic alliterative verse or something else? - RMN Newsletter 12-13: 139-161.

Kaukonen V. 1979. Lönnrot ja Kalevala. Helsinki: SKS.

Kiparsky P. 1968. Metrics and morphophonemics in the Kalevala. - Gribble C.E. (ed.). Studies presented to Professor Roman Jakobson by his students. Cambridge (MA): Slavica Publishers: 137-148.

Korhonen M. 1994. The early history of the Kalevala metre. - Siikala A.-L., Vakimo S. (eds.). Songs beyond the Kalevala. Transformations of oral poetry. Helsinki: SKS: 75-90.

Kuusi M. 1994. Questions of Kalevala metre. What exactly did Kalevala language signify to its users? - Siikala A.-L., Vakimo S. (eds.). Songs beyond the Kalevala. Transformations of oral poetry. Helsinki: SKS: 41-55.

Laugaste E. 1990. The Kalevala and Kalevipoeg. - Honko L. (ed.). Religion, myth, and folklore in the world's epics: The Kalevala and its predecessors. Berlin: Mouton de Gruyter: 265-285.

Leino P. 1994. The Kalevala metre and its development. - Siikala A.-L., Vakimo S. (eds.). Songs beyond the Kalevala. Transformations of oral poetry. Helsinki: SKS: 56-74.

Longfellow H.W. 1898. The song of Hiawatha. Chicago: Smith-Andrew.

Mead W.R. 1962. Kalevala and the rise of Finnish nationality. - Folklore 73.4: 217-229.

Moyne E.J. 1963. Hiawatha and Kalevala: A study of the relationship between Longfellow's "Indian edda" and the Finnish epic. Helsinki: Suomalainen Tiedeakatemia.

Punttila M., Issakainen T. 2003. Kalevala, kansanrunous ja kirjakieli. - Virittäjä 107.2: 226-245.

Räihä T. 2012. W.F. Kirby: hyönteistutkijan tuhat ja yksi yötä Kalevalan parissa. - Aarnipuu P. (ed.). Kalevala maailmalla: kansalliseepoksen kääntämisen kulttuurihistoriaa. Helsinki: SKS: 127-137.

Sadeniemi M. 1951. Die Metrik des Kalevala-verses. [= FF Communications 139]. Helsinki: Suomalainen Tiedeakatemia.

Schellbach-Kopra I. 1991. Kalevalametrum und Kalevalasprache als Charakteristika des Finnischen. - Tristram H.L.C. (ed.). Metrik und Medienwechsen. Tübingen: G. Narr: 129-140.

Setälä E.N. 1903. Kullervo - Hamlet. Ein sagenvergleichender versuch. - Finnisch-Ugrische Forschungen 3: 61-97.

Setälä E.N. 1907. Kullervo - Hamlet. Ein sagenvergleichender versuch. - Finnisch-Ugrische Forschungen 7: 188-264.

Setälä E.N. 1910a. Kullervo - Hamlet. Ein sagenvergleichender versuch. - Finnisch-Ugrische Forschungen 10: 44-127.

Setälä E.N. 1910b. Die Übersetzungen und Übersetzer des Kalevalas. - Finnisch-Ugrische Forschungen (Anzeiger) 10: 1-52.

Shippey T. 2001. J.R.R. Tolkien: The author of the century. London: HarperCollinsPublishers. SSA = Itkonen E., Kulonen U.-M. (eds.). 1992. Suomen sanojen alkuperä. [vol. 1]. Helsinki: SKS.

Voigt V. 1990. The Kalevala and the epic traditions in Europe. - Honko L. (ed.). Religion, myth, and folklore in the world's epics: the Kalevala and its predecessors. Berlin: Mouton de Gruyter: 247-264. 